\title{
PHYTOSEIID MITES OF THE CANARY ISLANDS (ACARI, PHYTOSEIIDAE). II. TENERIFE AND LA GOMERA ISLANDS
}

\author{
F. Ferragut* \& M. A. Peña-Estévez**
}

\begin{abstract}
Phytoseiid mites (Acari, Phytoseiidae) inhabiting plants in natural ecosystems from Tenerife and La Gomera islands (Canary Islands) have been studied. Surveys were conducted from 1997 to 2002 . Eleven species were collected, one of them being reported for the first time from the Canary Islands and six of them reported for the first time from Tenerife and La Gomera islands. Euseius machadoi n. sp. collected from woody plants in the Canarian laurisilva is proposed as a new species.
\end{abstract}

Key words: Acari, Phytoseiidae, Euseius machadoi, Tenerife, La Gomera, Canary Islands.

\section{RESUMEN}

\section{Ácaros Fitoseidos de las islas Canarias (Acari, Phytoseiidae).}

\section{Tenerife y La Gomera}

En muestreos realizados desde 1997 hasta 2002 se ha estudiado la fauna de ácaros fitoseidos (Acari, Phytoseiidae) asociada a plantas de ecosistemas naturales de las islas de Tenerife y La Gomera (Islas Canarias). Se han recolectado un total de 11 especies, siendo una de ellas citada por vez primera en las islas Canarias y seis de ellas citadas por primera vez en las islas de Tenerife y La Gomera. Euseius machadoi n. sp., recolectado en plantas leñosas de la laurisilva canaria, se propone como una nueva especie.

Palabras clave: Acari, Phytoseiidae, Euseius machadoi, Tenerife, La Gomera, Islas Canarias.

\section{Introduction}

The mite family Phytoseiidae includes about 2300 species, which are found in all parts of the world except the Polar Regions (Moraes et al., 2004). They are the most common group of predatory mites inhabiting higher plants, and the increa- se in our knowledge during the last 40 years has been due to their importance as biological control agents of pests on many crops (Helle \& Sabelis, 1985; Gerson et al., 2003).

Due to their agricultural importance, the species found in agricultural zones of Europe and North America are relatively well known, but little is

* Instituto Agroforestal Mediterráneo. Universidad Politécnica de Valencia. Camino de Vera, 14. 46022 Valencia. España. email: fjferrag@eaf.upv.es

** Área de Medio Ambiente del Cabildo de Gran Canaria, C/ Prof. Agustín Millares Carló, s/n, 1º , 35003, Las Palmas de Gran Canaria, España. e-mail: estevez1@auna.com 
known of those that occur in many natural ecosystems. However, our knowledge of phytoseiid species that live in natural or little altered (non-agricultural) ecosystems in the Canary Islands has grown substantially in recent years (Ferragut \& Peña-Estévez, 2003; Moraza et al., 2005; Moraza \& Peña-Estévez, 2005a, 2005b, 2006). Thus, 27 species are now known from such habitats, nine of them being endemic to the islands.

This study may be considered the second part of a previous publication (Ferragut \& Peña-Estévez, 2003) in which the phytoseiid species of Gran Canaria were studied and it is intended to increase our knowledge of this group of plant mites in Tenerife and La Gomera, presenting data on the species found, their relative importance, geographical distribution, habitat preference and host plants.

\section{Materials and Methods}

Several surveys were conducted from November 1997 to December 2002 on plants from natural nonagricultural ecosystems from Tenerife and $\mathrm{La}$ Gomera. A total of 145 samples were collected from Tenerife and 107 from La Gomera island. A list of localities, habitats and georeferencing data can be found in Appendix 1. Phytoseiid mites were collected using a mite brushing machine and Berlese funnels. The mites were cleared in Nesbitt fluid and mounted on Heinze-PVA medium. Observations were made using an interference contrast microscope. All measurements in this paper are given in micrometers $(\mu \mathrm{m})$. Setal nomenclature follows that of Rowell et al. (1978), and the nomenclature used for the dorsal solenostomes or gland openings (gd1gd9) is that proposed by Athias-Henriot (AthiasHenriot, 1975; Swirski et al., 1998). Generic nomenclature follows the criteria recently proposed by Chant \& McMurtry (2007). All the specimens were collected by M. A. Peña-Estévez. The holotype and paratypes of the new species are deposited in the Museo Nacional de Ciencias Naturales in Madrid (MNCN). Other type material can be found in the collection belonging to the Instituto Agroforestal Mediterráneo, Universidad Politécnica de Valencia.

\section{Results}

\section{SPECIES COLLECTED}

A total of 305 specimens were collected, 196 in Tenerife and 109 in La Gomera. The material was grouped into 11 species, seven from Tenerife and eight from La Gomera. The paper also includes the description of a new species of the genus Euseius Wainstein, 1962.

Family Phytoseiidae Berlese, 1916

Subfamily Amblyseiinae Muma, 1961

Amblyseius herbicolus (Chant, 1959)

Typhlodromus (Amblyseius) herbicolus. The Canadian Entomologist, 12: 84.

SPecimens EXAMINED - Tenerife: Eleven females on Viburnum rigidum (Caprifoliaceae) and 3 females on Woodwardia radicans (Blechnaceae), Hoya de Ijuana, 15 November 1997; 4 females on Laurus novocanariensis (Lauraceae), Pedro Alvarez, 29 November 1997; 8 females on Rubus ulmifolius (Rosaceae) and 16 females on Laurus novocanariensis (Lauraceae), El Moquinal, 29 November 1997; 5 females on Hedera helix (Araliaceae), Llano de los Viejos, 29 November 1997. La Gomera: One female on Laurus novocanariensis (Lauraceae), Bco. El Cedro, 30 May 2002; one female and one male on Rhamnus glandulosa (Rhamnaceae), Bosque de los Mástiles, 7 December 2002.

REMARKS - Species of a wide geographical distribution, including tropical and subtropical areas around the world. Previously reported from Gran Canaria by Ferragut \& Peña-Estévez (2003).

\section{Euseius machadoi new species}

TYPE MATERIAL. Holotype and paratypes deposited in MNCN (holotype catalog $\mathrm{n}^{\circ}$ 20.02/17046; paratypes $\mathrm{n}^{\circ} 20.02 / 17047$ and $\left.n^{\circ} 20.02 / 17048\right)$. Tenerife: Holotype female, 3 paratype females and 3 males on Myrica faya (Myricaceae), Las Rosas, 25 May 1999; 5 paratype females and 2 males on Laurus novocanariensis (Lauraceae), Pedro Alvarez, 29 November 1997. La Gomera: One paratype male on Ilex canariensis (Aquifoliaceae) and 1 paratype male on Hedera canariensis (Araliaceae), Chorros de Epina, 1 June 2002. Gran Canaria: One paratype female on Laurus novocanariensis, Zumacal, 14 December 1998.

DiAgnosis. Dorsal shield about 400 long. Dorsal surface smooth with a few anterolateral and posterior striae. Irregular lateral margins. Seventeen pairs of short, thick, pointed and smooth dorsal setae, except Z5 which is slightly serrated; the longest being j1, j3, s4 and Z5. Seven pairs of dorsal solenostomes: gd1, gd2, gd4, gd5, gd6, gd8 and gd9. Peritreme very short, reaching to level of z4. In the insemination apparatus the calix is long, cone-shaped and flaring distally. Ventrianal shield wider at the level of setae ZV2 than at level of anal opening. Four thick, sharp macrosetae on genu III, genu IV, tibia IV and tarsus IV. 


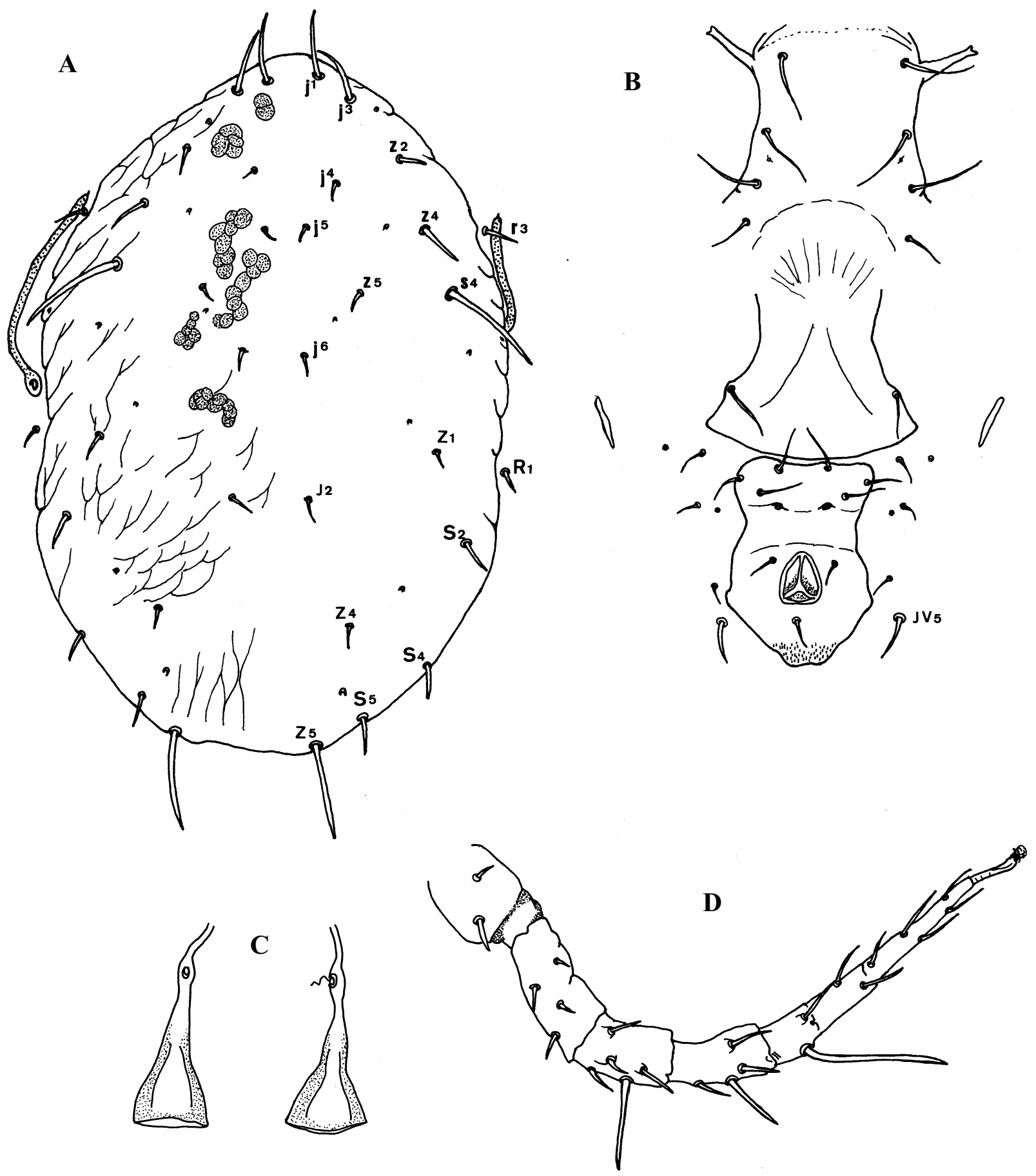

Fig. 1.-Euseius machadoi n. sp., female. A) dorsal shield, B) ventral surface, C) insemination apparatus, D) macrosetae on leg IV.

Fig. 1.-Euseius machadoi n. sp., hembra. A) escudo dorsal, B) superficie ventral, C) aparato inseminador, D) macroseta de la pata IV. 
Female (Fig. 1) (Dimensions of the holotype with the variations in the measurements of the paratypes in parentheses. Seven females measured).

Dorsum (Fig. 1A) - Oval-shaped dorsal shield, 404 long (354-410) and 270 wide (208-278). Dorsal surface smooth with a few lateral striae, faintly reticulated or striated posteriorly, especially in the region between $\mathrm{Z} 1$ and Z4. Irregular lateral margins, with indentations between $\mathrm{j} 3$ and $\mathrm{S} 2$. Seventeen pairs of thick, pointed and smooth setae, except Z5 which is slightly serrated. All setae short or very short, with $\mathrm{j} 1, \mathrm{j} 3$, s4 and Z5 being the longest. Setae j1: 40 (34-42); j3: $32(28-32) ; j 4$, j5 and j6: 8 (7-9); J2: 10 (8-10); J5: 8 (8-9); z2: 12 (11-13); z4: 24 (20-24); z5: 8 (7-9); Z1: 14 (12-15); Z4: 14 (11-14); Z5: 50 (46-52); s4: 58 (52-60); S2 and S4: 18 (16-18); S5: 20 (16-22); r3 and R1: 16 (14-17). Seven pairs of dorsal solenostomes: $\operatorname{gd} 1, \mathrm{gd} 2$ and gd5 small and punctiform; gd4, gd6 and gd8 punctiform and $\mathrm{gd} 9$ crescentic. Gland gd8 well separated and exterior to Z4, gland gd9 interior to S5. Peritreme very short, reaching to level of $z 4$. Peritremal shield terminating in sublateral integument.

Venter (Fig. 1B) - Smooth, quadrangular sternal shield, with three pairs of setae (ST1, ST2 and ST3). Posterior margin weakly sclerotized and difficult to discern. Setae ST4 apparently on the soft integument. Genital shield wider than ventrianal. Ventrianal shield vase-shaped, with smooth surface, 118 (104-120) long, slightly wider at level of seta ZV2, 78 (70-80), than at level of anal opening, 72 (66-72). With three pairs of preanal setae aligned in two transverse rows on the anterior third of the shield and a pair of crescentic preanal solenostomes. Four pairs of setae around the ventrianal shield, JV5 being pointed and thick, 20 (18-20). Primary metapodal plate 30 (26-33) long.

Spermatheca (Fig. 1C) - Calix long, cone-shaped, 32 (28-34), flaring distally, with walls and slightly bulging at the level of atrium.

Chelicerae - Short cheliceral digits; fixed digit with three small teeth, movable digit with one tooth.

Legs - Measurements of legs as follows: pI: 410; pII: 340; pIII: 376; p IV: 464. Macrosetae thick and sharp, present on genu III: 32 (26-32), genu IV: 62 (45-65), tibia IV: 40 (32-42) and tarsus IV: 92 (72-92) (Fig. 1D).

MALE (Fig. 2) (Four specimens measured).

Dorsum (Fig. 2A) - Oval dorsal shield, 310 long, 222 wide, with faintly marked striae on the lateral margins and irregular margins, especially in the opistonothal region. Seven pairs of solenostomes, gd1, gd2, gd4, gd5, gd6, gd8 and gd9. Nineteen pairs of smooth, thick and pointed dorsal setae. Setae $\mathrm{r} 3$ and R1 on dorsal shield; j1: 32 (28-33); j3: 32 (30-34); j4 and j5: 6 (5-6); j6: 9 (9-10); J2: 10 (10-11); J5: 6 (6); z2: 16 (15-18); z4: 25 (23-28); z5: 6 (6); Z1: 15 (14-16); Z4: 14 (13-16); Z5: 45 (4347); s4: 42 (40-44); S2 and S4: 20 (18-22); S5: 22 (20-26); r3 15 (14-16) and R1: 11 (11-12). Peritreme reaching the level of $\mathrm{z} 4$ or between z2-z4.

Venter - Triangular ventrianal shield 126 long (124-128) and 196 wide (189-204), fused with peritrematal shields (Fig. 2B), with striated surface, three pairs of preanal setae and preanal pores.

Chelicerae (Fig. 2C) - Fixed digit with 3 or 4 teeth distal to pilus dentilis, movable digit with 1 tooth.

Spermatodactyl (Fig. 2C) - L-shaped with a long foot, two apical lobes and a small pointed process. The outer margin of the shaft carries a membranous border.

Legs - Macrosetae on genu III not discernible; thick and sharp macrosetae on genu IV 36 (34-38), tibia IV 28 (28-30) and tarsus IV 72 (64-75).

Etymology: This species is dedicated to the coleopterologist Antonio Machado for his contribution to the knowledge of the arthropod fauna and the conservation of natural habitats in the Canary Islands.

REMARKS: E. machadoi is very similar morphologically to E. spermahyphus (Ueckermann \& Loots) described from South Africa on Senecio pterophorus (Ueckermann \& Loots, 1988). It differs from E. spermahyphus in the shape of the calyx in the spermatheca, long and cone-shaped in $E$. machadoi and long and filamentous in E. spermahyphus; the length of the peritremes, reaching setae $\mathrm{z} 4$ in E. machadoi and the level between z2z4 in E. spermahyphus; the number of teeth on the fixed digit of the chelicera, three small teeth in $E$. machadoi instead of 7 teeth in E. spermahyphus; and finally in the length of dorsal setae, which are shorter in E. spermahyphus.

Euseius scutalis (Athias-Henriot, 1958)

Typhlodromus scutalis. Revue de Patologie Vegetale et d'Entomologie Agricole, 37(2): 183

SPECIMENS EXAMINed - Tenerife: One female on Asparagus pastorianus (Liliaceae), Barranco del Infierno, 23 November 1997. 

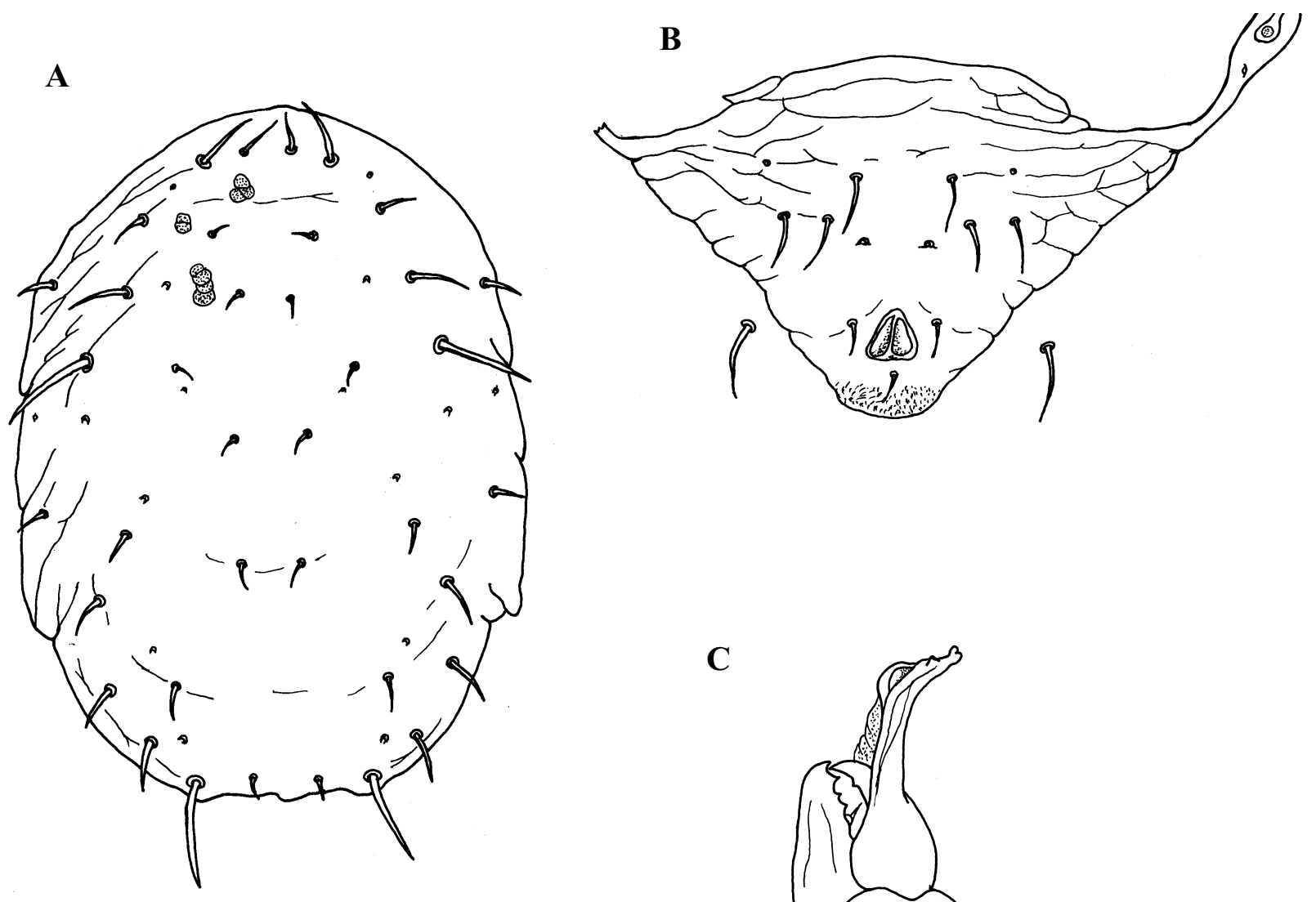

C

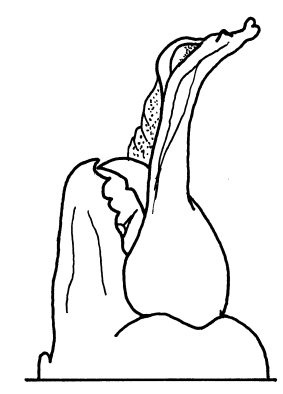

Fig. 2.-Euseius machadoi n. sp., male. A) dorsal shield, B) ventrianal shield, C) spermatodactyl and chelicera.

Fig. 2.-Euseius machadoi n. sp., macho. A) escudo dorsal, B) escudo ventroanal, C) espermatodáctilo y quelícero.

REMARKS - This species has been reported from a wide geographical area from the Macaronesia to India. Previously reported from Gran Canaria Island by Ferragut \& Peña-Estévez (2003).

Iphiseius degenerans (Berlese, 1889)

Seius degenerans. Tipografia del Seminario, 6(54): 9

SPeCimens EXAMINED - La Gomera: One female on Mentha sp. (Lamiaceae), Hornillo, 31 May 2002.

REMARKS - Species of tropical and subtropical distribution. Very common in all the Canary Islands on weeds and some crops. Reported from Tenerife Island by Pande et al., (1989).
Kampimodromus hmiminai McMurtry \& Bounfour, 1989 Acarologia, 30(1): 17

SPeCimens eXAmined - La Gomera: Ten females and 2 males on Salix canariensis (Salicaceae), Hornillo, 31 May 2002.

REMARKS - Described from northern Morocco by McMurtry \& Bounfour (1989), it is found in the Western Mediterranean, being collected in France (Tixier et al., 2006) and Spain (unpublished data). This is the first record of this species from the Canary Islands. Recent genetic studies (Tixier et al., 2006) show that it is conspecific with $K$. adrianae described by Ferragut \& Peña-Estévez (2003) in Gran Canaria island (see comments in Discussion). 
Neoseiulus californicus (McGregor, 1954)

Typhlodromus californicus. Southern California Academy of Science Bulletin, 53: 89

SPECIMENS EXAMINED - La Gomera: One female on Ricinus communis (Euphorbiaceae) and 1 male on Limonium sp. (Plumbaginaceae), San Sebastián, 29 May 2002.

REMARKS - Species with a worldwide distribution including those regions with a Mediterranean climate around the world. Very abundant in agricultural areas and commonly used to control spider mites of the genus Tetranychus Dufour in vegetable crops.

Neoseiulus liticellus (Athias-Henriot, 1966)

Amblyseius liticellus. Bulletin Scientifique de Bourgogne, 24 : 216

SPECIMENS EXAMINED - Tenerife: One female on Fumaria officinalis (Papaveraceae) and one female on Convolvulus arvensis (Convolvulaceae), Cruz de Tea, 18 April 2000.

REMARKS - Described from some specimens collected in Guinea, it has been previously reported from Gran Canaria by Ferragut and Peña-Estévez (2003).

Proprioseiopsis messor (Wainstein, 1960)

Typhlodromus messor. Zoologicheskii Zhurnal, 39: 688.

SPECIMENS EXAMINED - Tenerife: One female on Hedera helix (Araliaceae), Llano de Los Viejos, 29 November 1997.

REMARKS - This species has a worldwide distribution, it has been previously reported in the islands of La Gomera and Tenerife by Moraza \& Peña-Estévez (2005a, 2005b).

Subfamily Typhlodrominae Scheuten, 1857

\section{Typhlodromus (Anthoseius) rhenanoides Athias-Henriot,} 1960

Bulletin de la Société d'Histoire Naturelle de l'Afrique du Nord, 51: 85

SPeCimens EXAmined - Tenerife: Three females and 1 male on Prunus lusitanica (Rosaceae), Cruz del Carmen, 15 November 1997; 1 female on Erica arborea (Ericaceae), Tagaiga, 16 November 1997; 2 females on Ageratina adenophora (Asteraceae) and 2 females on Lavandula canariensis (Lamiaceae), Bco. del Infierno, 23 November 1997; 5 females and 2 males on Artemisia canariensis (Asteraceae), Bajamar, 29 November 1997; 3 males on Lavandula buchii (Lamiaceae), Bco. del Tomadero, 29 November 1997; 1 male on Erica arborea (Ericaceae), Pedro Alvarez, 29 November 1997; 5 females on Rubus ulmifolius (Rosaceae), El Moquinal, 29 November 1997; 1 female on Myrica faya (Myricaceae), Las Rosas, 25 May 1999; 3 females on Myrica faya (Myricaceae), 2 females on Prunus lusitanica (Rosaceae), 3 females, 2 males, 1 immature on Ilex canariensis (Aquifoliaceae), 1 male on Sonchus sp. (Asteraceae), 1 male on Laurus novocanariensis (Lauraceae), 2 females, 1 male, 1 immature on Hedera helix (Araliaceae), 13 females on Apollonias barbujana (Lauraceae) and 3 females on Viburnum rigidum (Caprifoliaceae), Llano de Los Viejos, 26 May 1999; 4 females on Laurus novocanariensis (Lauraceae) and 2 females on Geranium canariensis (Geraniaceae), El Tanque, 27 May 1999; 1 female on Ilex platyphylla (Aquifoliaceae) and 5 females, 4 males, 1 immature on Crambe strigosa (Cruciferae), Monte del Agua, 27 May 1999; 3 females on Echium virescens (Boraginaceae) and 1 female on Ceballosia fruticosa (Boraginaceae), Playa San Marcos, 27 May 1999; 1 male on Cistus monspeliensis (Cistaceae), Cruz de Tea, 18 April 2000; 4 females and 1 male on Myrica faya (Myricaceae), La Esperanza, 9 December 2001. La Gomera: One female on Schizogyne sericea (Asteraceae), Puntallana, 29 May 2002; 2 females on Viburnum rigidum (Caprifoliaceae), Apartacaminos, 30 May 2002; 1 female on Ageratina adenophora (Asteraceae), and 1 female on Persea indica (Lauraceae), Barranco El Cedro, 30 May, 2002; 1 female on Bistropogon canariensis (Lamiaceae) and 1 female on Gonospermum gomerae (Asteraceae), Meriga, 30 May 2002; 1 female on an unidentified plant, Nariga, 1 June 2002; 1 female and 1 immature on Erica scoparia (Ericaceae), Mirador E1 Bailadero, 6 December 2002; 1 female and 1 male on Cedronella canariensis (Lamiaceae), Barranco El Cedro, 6 December 2002; 4 females and 4 males on Bystropogon canariensis (Lamiaceae), Mirador Tajaque, 6 December 2002; 1 female and 1 male on Rhamnus integrifolia (Rhamnaceae), Roque Cano, 7 December 2002; 3 females and 3 males on Maytenus canariensis (Celastraceae), Teselinde, 7 December 2002; 1 female and 1 male on Maytenus canariensis (Celastraceae), Las Rosas, 7 December 2002

REMARKS - This species has a Western Mediterranean distribution, although it has also been found in the French Antilles, Hawaii and the United States. According to previous records, it is the most common phytoseiid species on plants from non cultivated areas in the Canary Islands. It was reported for the first time in the Islands by Ferragut \& Peña-Estévez (2003).

\section{Typhlodromus (Anthoseius) maspalomensis Ferragut \&} Peña-Estévez, 2003

International Journal of Acarology, 29(2): 158

SPECIMENS EXAMINED - La Gomera: One female on Schizogyne sericea (Asteraceae) and 12 females and 2 males on Tamarix canariensis (Tamaricaceae), Playa del Inglés, 31 May 2002; 1 female on Rumex acetosella (Polygonaceae), Argaga, 31 May 2002; 9 females and 2 males on Retama raetam (Leguminosae), Nariga, 1 June 2002.

REMARKS - Endemic phytoseiid mite described by Ferragut \& Peña-Estévez on plants in coastal sand dunes from the Reserva Natural Especial de Las Dunas de Maspalomas (Gran Canaria). 
Neoseiulella canariensis Ferragut \& Peña-Estévez, 2003 International Journal of Acarology, 29(2): 159

SPECIMENS EXAMINED - Tenerife: One female on Convolvulus sp. (Convolvulaceae), Barranco del Infierno, 23 November 1997; 1 male on Argyranthemum frutescens (Asteraceae), Bajamar, 29 November 1997; 1 female on Lavandula buchii (Lamiaceae), Barranco del Tomadero, 29 November 1997; 7 females, 2 males and 1 immature on Viburnum rigidum (Caprifoliaceae), Llano de los Viejos, 26 May 1999; 2 females and 1 immature on Senecio tussilaginis (Asteraceae) and 4 females and 1 male on Calamintha sylvatica (Lamiaceae), El Tanque, 27 May, 1999; 1 female on Geranium canariensis (Geraniaceae), 5 females and 3 males on Senecio tussilaginis (Asteraceae), 2 males on Crambe strigosa (Cruciferae), 1 female on Cedronella canariensis (Lamiaceae) and 8 females and 2 males on Viburnum rigidum (Caprifoliaceae), Monte del Agua, 27 May 1999; 1 male on Argyranthemum gracile (Asteraceae), Palm Mar, 18 April 2000. La Gomera: One female on Viburnum rigidum (Caprifoliaceae) and 1 male on Cedronella canariensis (Lamiaceae), Apartacaminos, 30 May 2002; 1 female on Laurus novocanariensis (Lauraceae), 3 females and 2 males on Gesnouinia arborea (Urticaceae), 1 male on Scrophularia smithii (Scrophulariaceae) and 1 male on Viola riviniana (Violaceae), Barranco El Cedro, 30 May 2002; 4 males on Echium acanthocarpum (Boraginaceae) and 1 male on Teline gomerae (Leguminoseae), Meriga, 30 May 2002; 2 females and 2 males on Erica scoparia (Ericaceae), Mirador El Bailadero, 6 December 2002; 3 females, 1 male and 2 immatures on Gonospermum gomerae (Asteraceae), Las Rosas, 7 December 2002; 1 female and 1 male on Andryala pinnatifida (Asteraceae), Teselinde, 7 December 2002.

REMARKS - Species described from Gran Canaria (Ferragut \& Peña-Estévez, 2003). Apparently, the distribution range includes other islands in the Canaries.

\section{RELATIVE ABUNDANCE OF PHYTOSEIID MITE SPECIES}

Table 1 show the species captured on each island, their abundance, relative importance and frequency of appearance in the total samples. The results show that Typhlodromus (Anthoseius) rhenanoides and Neoseiulella canariensis are the most abundant species in the prospected zones of the two islands, with Amblyseius herbicolus and Typhlodromus (Anthoseius) maspalomensis also being abundant species in Tenerife and La Gomera, respectively. The relative importance of these species is confirmed because they constitute more than $90 \%$ of the phytoseiid collected in Tenerife and $85 \%$ in La Gomera. The rest of the species are scarce or are associated with one of the plants collected.

Typhlodormus rhenanoides is also the most frequent species, since it appears in $18 \%$ of the Tenerife samples and $12 \%$ of those from $\mathrm{La}$ Gomera. Neoseiulella canariensis is the second most frequent, appearing in more than $8 \%$ of sam- ples from Tenerife and 11.2\% from La Gomera. The frequency of appearance of the other species, even A. herbicolus and T. maspalomensis, is low, since they were found in few samples, although their abundance was quite high.

\section{Discussion}

This study reports the presence of 11 phytoseiid species in little altered habitats of Tenerife and La Gomera islands. Only one, Kampimodromus hmiminai, had not previously been reported for the Canary Islands (see commentary on this species) and another, Euseius machadoi, is proposed as a new taxon for science. This means that the results obtained were relatively poor despite the effort put into sampling and the period during which the samples were collected. The paucity is even more notable if we compare the results obtained in Gran Canaria with a similar sampling effort, when 21 species of phytoseiids were captured, six of them new species (Ferragut \& Peña-Estévez, 2003) and take into account that the ecosystems sampled, which included the laurisilva and the National Parks Las Cañadas del Teide and Garajonay, are known to be rich in species of other arthropods. Perhaps other reasons such as differences between sampling periods or the plant diversity of ecosystems could better explain these results.

The relative importance of the different species is similar to that found in Gran Canaria, where $T$. rhenanoides and $N$. canariensis are the most common species on plants in non-altered environments.

The new taxon described, Euseius machadoi, was found on both islands, and on Gran Canaria, which means it is widespread distributed, although it is not abundant. It also seems to be associated with woody plants typical of the Canarian monteverde, such as Laurus novocanariensis, Myrica faya and Ilex canariensis, characterised by large smooth leaves with no hairs or trichomes.

On La Gomera, we collected $K$. hmiminae, a species considered until recently as very close to Kampimodromus adrianae Ferragut \& PeñaEstévez, 2003 described from Gran Canaria. In a recent morphological and genetic study of both species, using specimens of $K$. adrianae from Gran Canaria and K. hmiminae from France and Morocco, Tixier et al., (2006) found that, although morphologically similar, the species can be easily distinguished by the length of their dorsal setae. However, a comparison of mitochondrial DNA fragments showed that the differences 
Table 1.- Abundance of phytoseiid species collected in Tenerife and La Gomera Islands. Abundance is the total number of mites, relative abundance is the percentage of each species compared with the total number of phytoseiids and frequency is the frequency of occurrence of each species on the total samples taken in Tenerife and La Gomera.

Tabla 1.- Abundancia de las especies de fitoseidos recolectadas en las islas de Tenerife y La Gomera. Abundancia es el número total de ejemplares de cada especie, abundancia relativa el porcentaje de cada especie en relación al número total de fitoseidos y frecuencia la frecuencia de aparición de cada especie en el total de muestras tomadas en Tenerife y La Gomera.

\begin{tabular}{|c|c|c|c|}
\hline & \multicolumn{3}{|c|}{ Phytoseiid mites from Tenerife } \\
\hline & abundance & relative abundance & frequency \\
\hline Typhlodromus rhenanoides & 86 & $43.9 \%$ & $17.9 \%$ \\
\hline Amblyseius herbicolus & 47 & $24.0 \%$ & $4.1 \%$ \\
\hline Neoseiulella canariensis & 44 & $22.5 \%$ & $8.3 \%$ \\
\hline Euseius machadoi $\mathbf{n} . \mathbf{s p .}$ & 15 & $7.6 \%$ & $1.4 \%$ \\
\hline Neoseiulus liticellus & 2 & $1.0 \%$ & $1.4 \%$ \\
\hline Euseius scutalis & 1 & $0.5 \%$ & $0.7 \%$ \\
\hline Proprioseiopsis messor & 1 & $0.5 \%$ & $0.7 \%$ \\
\hline Total & 196 & & \\
\hline
\end{tabular}

\begin{tabular}{lccc}
\hline & \multicolumn{3}{c}{ Phytoseiid mites from La Gomera } \\
\cline { 2 - 4 } & abundance & relative abundance & frequency \\
\hline Neoseiulella canariensis & 41 & $37.6 \%$ & $11.2 \%$ \\
Typhlodromus maspalomensis & 27 & $24.8 \%$ & $3.7 \%$ \\
Typhlodromus rhenanoides & 21 & $19.3 \%$ & $12.1 \%$ \\
Kampimodromus hmiminai & 12 & $11.0 \%$ & $0.9 \%$ \\
Amblyseius herbicolus & 3 & $2.8 \%$ & $1.9 \%$ \\
Neoseiulus californicus & 2 & $1.8 \%$ & $1.9 \%$ \\
Euseius machadoi $\mathbf{n} . \mathbf{s p}$. & 2 & $1.8 \%$ & $1.9 \%$ \\
Iphiseius degenerans & 1 & $0.9 \%$ & $0.9 \%$ \\
\hline \multicolumn{1}{c}{ Total } & $\mathbf{1 0 9}$ & & \\
\hline
\end{tabular}

are less than might be expected in different species, so that any morphological differences may be due to intraspecific variability. The variation in dorsal seta length, one of the most widely used characters in the taxonomy of phytoseiids for separating species, had already been discussed in the case of Kampimodromus aberrans (Oudemans, 1930) by Chant (1955) and Ragusa \& Tsolakis (1994). These authors observed that two forms of the species existed, one of which appeared in summer with long, serrated dorsal setae and the other in winter with shorter, thinner and less serrated dorsal setae. However, the appearance of larger setae in summer does not seem to be a characteristic of $K$. adrianae/K. hmiminae, since most of the specimens of $K$. adrianae (lar- ger and thicker setae) were collected in the Canary Islands in November (some in August), while $K$. hmiminae (smaller, thinner setae) was collected in May. Curiously, both species, or morphospecies, were always found associated with the same host plant, the endemic Salicaceae Salix canariensis.

\section{ACKNOWLEDGEMENTS}

The authors wish to thank the authorities from the Cabildos of Tenerife and La Gomera islands, and the National Parks of Cañadas del Teide and Garajonay for providing the permits to collect the samples. 


\section{References}

Athias-HenRiot, C., 1975. Nouvelles notes sur les Amblyseiini. II. Le relevé organotaxique de la face dorsal adulte (Gamasides, Protoadéniques, Phytoseiidae). Acarologia, 27: 20-29.

Chant, D. A., 1955. Notes on mites of the genus Typhlodromus Scheuten, 1857 (Acarina: Laelaptidae), with descriptions of the males of some species and the female of a new species. The Canadian Entomologist, 87: 496-503.

Chant, D. A. \& McMurtry, J. A., 2007. Illustrated keys and diagnoses for the genera and subgenera of the Phytoseiidae of the World (Acari : Mesostigmata). Indira Publishing House. West Bloomfield. 220 pp.

Ferragut, F. \& Peña-Estévez, M. A., 2003. Phytoseiid mites of the Canary Islands (Acari: Phytoseiidae). 1: Gran Canaria Island. International Journal of Acarology, 29(2): 149-167.

Gerson, U., Smiley, R. L. \& Ochoa, R., 2003. Mites (Acari) for pest control. Blackwell. Oxford, $539 \mathrm{pp}$.

Helle, W. \& SABelis, M. W., 1985. Spider mites: their biology, natural enemies and control. World Crop Pests, vol. 1 B. Elsevier. Amsterdam. 458 pp.

McMurtry, J. A. \& Bounfour, M., 1989. Phytoseiid mites of Morocco, with descriptions of two new species and notes on the genera Kuzinellus, Typhloctonus and Typhlodromus (Acari: Phytoseiidae). Acarologia, XXX: 13-24.

Moraes G. J., McMurtry, J. A., Denmark, H. A. \& CAMPos, C. B., 2004. A revised catalog of the mite family Phytoseiidae. Zootaxa, 434: 1-494.

MorazA, M. L. \& PeÑA-Estévez, M. A., 2005a. Ácaros Mesostigmata (Acari: Mesostigmata) de hábitats seleccionados de La Gomera (Islas Canarias, España). Graellsia, 61(1): 109-114.

MorazA, M. L. \& PeÑA-Estévez, M. A., 2005b. Ácaros Mesostigmata (Acari: Mesostigmata) en hábitats seleccionados de la isla de Tenerife (Islas Canarias). Revista Ibérica de Aracnología, 11: 61-68.

MorazA, M. L. \& Peña-Estévez, M. A., 2006. A new species of Neoseiulella (Acari: Phytoseiidae) from the Macaronesian Region, Canary Islands. Zootaxa, 1366: 55-59.

Moraza, M. L., Peña-Estévez, M. A. \& Ferragut, F., 2005. Two new species of Neoseiulella Muma of the Canary Islands (Acari: Phytoseiidae). International Journal of Acarology, 31(1): 107-112.
Pande, Y. D., Carnero, A. \& Hernández, M., 1989. Notes on biological observations on some unrecorded species of phytophagous and predatory mites in Canary Islands. Invesigación Agraria: Producción y Protección Vegetal, 4: 275-281.

Ragusa, S. \& Tsolakis, H., 1994. Revision of the genus Kampimodromus Nesbitt, 1951 (Parasitiformes: Phytoseiidae), with a description of a new species. Acarologia, XXXV: 305-322.

Rowell, H. J., Chant, D. A. \& Hansell, R. I. C., 1978. The determination of setal homologies and setal patterns on the dorsal shield in the family Phytoseiidae (Acarina: Mesostigmata). Canadian Entomologist, 110: 859-876.

Swirski, E., Ragusa, S. \& Tsolakis, H., 1998. Keys to the phytoseiid mites (Parasitiformes: Phytoseiidae) of Israel. Phytophaga, VIII: 85-154.

Tixier, M. S., Kreiter, S., Ferragut, F. \& Cheval, B., 2006. The suspected synonymy of Kampimodromus hmiminai and Kampimodromus adrianae (Acari: Phytoseiidae): morphological and molecular investigations. Canadian Journal of Zoology, 84(8): 12161222.

Ueckermann, E. A. \& Loots, G. C., 1988. The African species of the subgenera Anthoseius De Leon and Amblyseius Berlese (Acari: Phytoseiidae). South Africa Department of Agriculture and Water Supply Entomology Memoir, 73: 1-168.
Recibido, 20-IX-2007

Aceptado, 7-XII-2007 Publicado, 27-XII-2007 
Appendix 1.- List of localities, plants collected and geographical data.

Apéndice 1.- Lista de localidades, plantas recolectadas y datos geográficos.

\begin{tabular}{|c|c|c|c|}
\hline \multicolumn{4}{|c|}{ Tenerife Island } \\
\hline LOCALITY & HABITAT & ALTITUDE & UTM \\
\hline Bajamar & Cardonal-tabaibal (xerophytic coastal vegetation) & 400 & $28 \mathrm{RCS} 316276$ \\
\hline Barranco del Infierno & Saucedal (willow community) & 600 & $28 \mathrm{RCS} 316276$ \\
\hline Barranco del Tomadero & Cardonal-tabaibal (xerophytic coastal vegetation) & 180 & 28RCS711604 \\
\hline Cruz de Tea & Shrubs and abandoned crops & 1100 & 28RCS415128 \\
\hline Cruz del Carmen & Laurisilva (evergreen or laurel forests) & 960 & $28 \mathrm{RCS} 749565$ \\
\hline El Moquinal & Laurisilva (evergreen or laurel forests) & 800 & $28 \mathrm{RCS} 731575$ \\
\hline El Tanque & Laurisilva (evergreen or laurel forests) & 820 & 28RCS244364 \\
\hline Hoya de Ujuana & Laurisilva (evergreen or laurel forests) & 740 & 28RCS856596 \\
\hline La Esperanza & Pinewoods & 1200 & 28RCS600438 \\
\hline Las Rosas & Pinewoods & 1100 & 29RCS653455 \\
\hline Llano de los Viejos & Laurisilva (evergreen or laurel forests) & 900 & 28RCS743561 \\
\hline Monte del Agua & Laurisilva (evergreen or laurel forests) & 700 & $28 \mathrm{RCS} 218355$ \\
\hline Palm Mar & Cardonal-tabaibal (xerophytic coastal vegetation) & 15 & $28 \mathrm{RCS} 326006$ \\
\hline Pedro Alvarez & Laurisilva (evergreen or laurel forests) & 780 & 28RCS719570 \\
\hline Playa San Marcos & Cardonal-tabaibal (xerophytic coastal vegetation) & 80 & 28RCS314399 \\
\hline Tagaiga & Laurisilva (evergreen or laurel forests) & 1400 & 28RCS444360 \\
\hline
\end{tabular}

\section{La Gomera Island}

\begin{tabular}{llcc}
\hline LOCALITY & HABITAT & ALTITUDE & UTM \\
\hline Apartacaminos & Monteverde (laurisilva and fayal-brezal) & 1080 & 28 RBS748158 \\
Argaga & Sand coastal communities & 1 & 28 RBS718082 \\
Barranco El Cedro & Monteverde (laurisilva and fayal-brezal) & 900 & 28 RBS816126 \\
Chorros de Epina & Monteverde (laurisilva and fayal-brezal) & 700 & 28 RBS748178 \\
Hornillo & Riparian communities & 350 & 28 RBS731120 \\
Meriga & Monteverde (laurisilva and fayal-brezal) & 800 & 28 RBS812150 \\
Nariga & Thermophilous forest & 450 & 28 RBS725154 \\
Playa del Inglés & Tarajaledas (tamarisk community) & 1 & 28 RBS696110 \\
Puntallana & Sand coastal communities & 2 & 28 RBS935132 \\
San Sebastián & Open fields & 400 & 28 RBS880126 \\
Teselinde & Monteverde (laurisilva and fayal-brezal) & 800 & 28 RBS75s6212 \\
\hline
\end{tabular}

